\title{
BIRD NOTES FOR THE ELBOW REGION, SASKATCHEWAN*
}

by Michael A. Gollop, 2202 York Avenue and Alan R. Smith, Department of Biology, University of Saskatchewan, Saskatoon

For two summers B. E. Felske, D. A. Sadler, and the authors have studied birds on the Matador Grassland Project in an area between Kyle and Beechy on the north side of Lake Diefenbaker. Most field work was done within five miles of the International Biological Programme field station near :Matador (Sect.15-20-13W3), approximately 27 miles southeast of Kyle. This is in the southwestern corner of a region for which Roy (1964) recently compiled a preliminary list of birds. This region covers a rectangle 24 miles from north to south (Townships 19-22 inclusive) and 30 miles from east to west (Ranges 11-15 inclusive, west of the Third Meridian). Roy's report was published prior to the construction of Gardiner Dam on the South Saskatchewan River and the subsequent formation of Lake Diefenbaker.

In 1967 we were in the area from May 22 to August 28, and in 1968, from May 2 to September 27. Several visits were made in winter months to obtain data on resident species. Of the 222 species recorded by Roy, 149 were observed by us. Six additional species are reported for the Elbow region: five were recorded by us; one species recorded in the literature had evidently been overlooked by Roy. This brings the total for the region to 228 species. Apparent changes in status of several species are recorded as well as records of two species considered rare in the region.

\section{Species not Listed by Roy}

HARLEQUIN DUCK (Histrionicus histrionicus). As reported by Houston, Bard, and Nero (1958), on May 31, 1934 an adult male was collected out of a flock of "several pairs" at Saskatchewan Landing. The locality is within the extreme southwestern corner of the Elbow region.

*Issued as Canadian IBP No. CCIBP 22.
OSPREY (Pandion haliaetus). An individual, a p parently southbound, landed at the field station on September 9, 1968.

PIPING PLOVER (Charadrius melodus). A female and two downy young were seen on August 10, 1967, near an alkali slough south of Clearwater Lake. The young were collected and are now in the University of Saskatchewan Biology Museum. This is a new breeding locality for Saskatchewan; the nearest known breeding localities include Crane Lake, Old Wives Lake and Strehlow.

YELLOW-BELLIED FLYCATCH$\mathrm{ER}$ (Empidonax flaviventris). A migrant was collected in a small ravine 2.5 miles east of Saskatchewan Landing on August 13, 1968.

B A Y-B R E A S TE D WARBLER (Dendroica castanea). On August 12 1958 an individual in fall plumage was observed in a large coulee 5.5 miles east of Saskatchewan Landing

BREWER'S SPARROW (Spizella breweri). A singing male was observed one mile southwest of the Research Station, along the brushy slopes of a small coulee on June 18, 1968. This sighting is far to the north of the known breeding range in the province The date and behaviour sugges breeding but more information i needed.

Apparent Status Changes

The following species of birds wer noted at times, places or in number different from previous data.

COMMON LOON (Gavia immer) Two were noted on Lake Diefenbakes in 1968. Loons may be expected to b more common in the future due to the influence of the large impoundment Roy gives only two records.

S NOW GOOSE (Chen caem lescens). Over 500 were observed Sep tember 26, 1968, on a slough approxi mately 5 miles north of the Beechy. 
Co-op Farm. This compares with Roy's previous high count of 270 birds.

CINNAMON TEAL (Anas cyanoptera). A male was observed at a small dam approximately 1.5 miles north of the field station on May 29, 1967. Roy gives one record.

RED-T A L L D HAWK (Buteo jamaicensis). Recorded as a rare migrant in 1967 and 1968. Roy reported it an uncommon migrant and summer resident, most regular in the South Saskatchewan River Valley and adjacent coulees. Rising waters, which flooded many of the large trees in the river valley, have probably been responsible for the apparent decline in population.

RED-EYED VIREO (Vireo olivaceous). Not recorded in 1967-1968. Reported by Roy as an "uncommon transient . . . likely breeds in the South Saskatchewan River valley..."

WARBLING VIREO (Vireo gil$v u s)$. Not recorded in 1967-1968. Reported by Roy as a "fairly common summer resident." This and the above species are the most striking examples of status change effected by the flooding of the valley.

YELLOW - B R E A S TED CHAT (Icteria virens). We recorded one individual on July 28, 1967. Roy notes that a Saskatchewan Museum of Natural History party found them fairly common in the valley from Demaine westward in June of 1961.

B ULL OCK'S ORIOLE (Icterus bullockii). Three were sighted immediately south of the field station on May 27, 1967. Considered a "sporadic summer visitant" by Roy.

\section{Acknowledgements}

We wish to thank our fellow team members and Dr. William J. Maher, University of Saskatchewan, who supervised the programme. Financial support was by the National Research Council.

\section{LITERATURE CITED}

Houston, C. S., F. G. Bard, and R. W. Nero. 1958. Further information on certain unusual Saskatchewan bird records. Blue Jay, $16: 64-65$.

Roy, J. F. 1964. An introduction to the birds of the Elbow. Saskatchewan Natural History Society, Regina. Mimeo., 33 pp.

\section{NESTING RECORDS OF THE YELLOW RAIL IN SASKATCHEWAN}

\section{by C. Stuart Houston, Saskatoon}

The only unequivocal published record of a Yellow Rail nest in Saskatchewan is that of Edward Arnold, an oologist who found a nest with four eggs at the west end of Pasqua Lake west of Fort Qu'Appelle on May 31, 1895 (Arnold, 1896). In 1924, R. D. Symons found a nest recently trampled by cattle, believed to be of this species, in the Arm River Valley east of Davidson (Symons, 1956). The following records for the Yorkton area seem entirely plausible and therefore worth recording.

In the early 1930's, the late Charles H. Maddaford ran over two nests while mowing hay, on the NW quarter of section 16, township 23, range 3 , west of the second meridian - nine miles west and three miles south of Saltcoats, Saskatchewan. Both nests were in long grass on damp ground at the edge of water and each contained six or eight eggs. A small yellowish rail flushed off each nest, and he was certain they were not Soras, a familiar species whose nests he found nearly every year. The eggs were also different from those of the Sora; in telling me of this more than 20 years later, he thought they were lighter in color. He was certain of his identification of both the birds and their eggs because he had checked them carefully at the time in his bird book.

Mr. Maddaford showed me the book from which his identification had been made, but unfortunately much use had worn the letters from its cover and the title page had fallen out. There was no other identification anywhere in the book! He gave me the book, which I sent to a dealer in second- 